\title{
Potret Sistem Agribisnis Pengolahan Hasil Perikanan Di Pesisir Pantai Selatan Kabupaten Garut
}

\author{
Portrait of Fishery Processing AgribusinessSystem \\ in The Coastal of the South Coast of Garut District \\ Ganjar Wiryati ${ }^{1}$, Ade Sunaryo, Tuti Susilawati, Ani Leilani \\ Jurusan Penyuluhan Perikanan, Sekolah Tinggi Perikanan \\ Jl.Cikaret No. 2 Bogor Selatan 16132
}

\begin{abstract}
The purpose of this study was to determine the types of processed fisheries produced in the southern coast of Garut Regency and find out the fishery processing agribusiness system on the southern coast of Garut Regency. The method used in the study is descriptive method with qualitative and quantitative approaches. Sampling by purposive sampling. Sampling was conducted on 30 fish processing business people in six subdistricts (Pameungpeuk, Mekarsari, Cikelet, Caringin, Pakenjeng, Cibalong). Data collection techniques by means of interviews using questionnaire instruments containing a list of questions. In data processing, the determination of values (scores) for each question in each subsystem (subsystem of procurement and distribution of fisheries production facilities, production business subsystems, post production subsystems, marketing subsystems, supporting service subsystems). Research results obtained information on the types of processed that are produced include, salted fish, pindang fish, shredded fish, fish meatballs, crackers, nuget, agar-agar. Next in the review of the five business subsystems obtained values (Scores) Subsystems for procurement and distribution of facilities (7.7), production business subsystems, (10.2), post-production systems (7), marketing subsystems (9.3), sub supporting service system (9.6) from the results of the assessment obtained a portrait of fishery processing agribusiness in the South Coast of Garut Regency. The results of this study can be used as a reference to develop processing activities of fishery results on the southern coast of Garut Regency.
\end{abstract}

Keywords: Agribusiness, processing, fishery products

\begin{abstract}
Abstrak
Tujuan dari penelitian ini adalah untuk mengetahui Jenis-jenis hasil olahan perikanan yang diproduksi di pesisir pantai selatan Kabupaten Garut dan mengetahui sistem agribisnis pengolahan hasil perikanan di pesisir pantai selatan Kabupaten Garut. Metodeyang di gunakan dalam penelitian adalah metodedeskriftif dengan pendekatan kualitatif dan kuantitatif. Pengambilan sample secara purposive sampling. Samplingdilakukan terhadap 30 orang pelaku usaha pengolahan ikan yang ada di enam Kecamatan ( Pameungpeuk, Mekarsari, Cikelet, Caringin, Pakenjeng, Cibalong).Teknik pengambilan data dengan cara wawancara menggunakan intrumen kuesioneryang berisi daftar pertanyaan. Dalam pengolahan data dilakukan penetapan nilai ( skor) terhadap setiap pertanyaan yang berada pada setiap subsistem (subsistem pengadaan dan penyaluran Sarana produksi perikanan, subsistem usaha produksi, subsistem pasca produksi, subsistem pemasaran, subsistem jasa penunjang). Hasil Penelitian di peroleh infomasi jenis-jenis olahan yang di produksi meliputi, ikan asin, ikan pindang, abon ikan, baso ikan, kerupuk, nuget, agar-agar. Selanjutnya di tinjau dari lima subsistem usaha di peroleh nilai (Skor) Subsistem pengadaan dan penyaluran sarana $(7,7)$, Subsistem usaha produksi, (10,2), Susistem pasca produksi (7), Subsistem pemasaran $(9,3)$, Sub sistem jasapenunjang $(9,6)$ dari hasil penilaian tersebut di peroleh potret agribisnis pengolahan hasil perikanan di Pesisir Selatan Kabupaten Garut. Hasil Penelitian ini dapat di jadikan referensi untuk mengembangkan kegiatan pengolahan hasil perikanandi pesisir selatan Kabupaten Garut.
\end{abstract}

Kata kunci: Agribisnis,pengolahan, hasil perikanan

\footnotetext{
${ }^{1}$ Korespondensi penulis

E-mail: gj.wiryati@gmail.com
} 


\section{Pendahuluan}

Wilayah pesisir memiliki keragaman potensi sumber daya alam yang tinggi dan sangat penting bagi pengembangan sosial, ekonomi, budaya dan lingkungan, sehingga perlu dikelola secara berkelanjutan, dengan memperhatikan aspirasi dan partisipasi masyarakat. Dengan berkembangan teknologi dan tuntutan ekonomi keluarga kaum perempuan juga telah berpartisipasi dalam kegiatan pengolahan dan penjualan hasil tangkapan. Aspek lain yang juga dilakukan oleh kaum perempuan adalah adanya kontribusi dalam ekonomi rumah tangga perikanan (Harper dkk., 2013). Perikanan laut di Indonesia sebagian besar merupakan perikanan rakyat, dan hanya sebagian kecil merupakan perikanan industri.Perikanan rakyat sendiri hingga saat ini masih bersifat tradisional, artinya pengolahan yang dilakukan belum banyak menerima atau menerapkan informasi dari luar yang lebih modern, bersifat turun temurun dan menggunakan peralatan yang sederhana.

Kabupaten Garut merupakan wilayah yang dinamis, seiring dengan bertambahnya waktu, berbagai dinamika terus berlangsung, baik yang diharapkan maupun yang tidak sehingga perubahan terjadi pada semua sektor. Wilayah Kabupaten Garut secara geografis terletak di Jawa Barat Selatan meliputi areal seluas 3.066,88 km2, terdiri dari 42 kecamatan, 403 desa, dan 21 kelurahan masing-masing mempunyai ciriciri khusus dalam potensi wilayah baik dari segi sumber daya alam maupun sumber daya manusianya (Dinas Peternakan Perikanan dan Kelautan Garut 2013). Kabupaten Garut memiliki panjang garis pantai sekitar $80 \mathrm{~km}$ yang membentang di wilayah selatan meliputi Kecamatan Caringin, Mekarmukti, Bungbulang, Pakenjeng, Cikelet, Pameungpeuk dan Cibalong.

Ditinjau dari potensi sumberdaya manusia, Kabupaten Garut memiliki sumberdaya manusia yang mencakup masyarakat perikanan dan kelautan, yang terdiri dari Pembudidaya ikan , Nelayan (termasuk pengolah ikan) Sumberdaya manusia pengolah pindang 505 rumah tangga perikanan pengolah buruh nelayan/pengolah 1.010, kelompok pengolah 25 kelompok (Dinas Peternakan Perikanan dan Kelautan Garut 2013). Menurut Hilda, (2010).Potensi perikanan tangkap kabupaten Garut diantara-nya Tuna, Tongkol, Cakalang, Cumi-cumi, Layur, Kakap, Bawal Hitam, Kerapu, Baronang, Cucut Botol, Lobster dan ikan khias. Khusus untuk area penangkapan sampai zona teritorial (12 mil laut) diperkirakan pesisir selatan Garut memiliki potensi lestari (Maximum Sustainable Yield) sebesar 10.000 ton/tahun.

Industri Perikanan yang ada pada saat ini merupakan industri perikanan rakyat yang masih bersifat tradisional, artinya pengolahan yang dilakukan belum banyak menerima atau menerapkan informasi dari luar yang lebih modern, bersifat turun temurun dan menggunakan peralatan yang sederhana. Melihat potensi perikanan tangkap yang ada di kabupaten Garut mendorong masyarakat sekitar pesisir pantai untuk mengolah sumberdaya tersebut dengan berbagai olahan ikan dan merupakan mata pencaharian dominan yang di geluti.

Pada proses kegiatan nya kegiatan usaha pengolahan yang dilakukan oleh masyarakat pesisir tersebut tidak terlepas dari sub-sub sistem Agribisnis perikanan yang merupakan serangkaian sistem yang tidak dapat di pisahkan satu sama lain. Mata Rantai sistem agribisnis perikanan laut dan perikanan darat terdiri dari lima rangkaian kegiatan ekonomi berupa subsistem pengadaan dan penyaluran saprokan (Sarana produksi perikanan), subsistem usaha produksi, subsistem pasca produksi, subsistem pemasaran, subsistem jasa penunjang Masyhuri (2005). Aktivitas industri pengolahan ikan yang digeluti 
masyarakat pesisir kabupaten Garut yang sangat bervariasi sehingga menyebabkan penting untuk melihat potret dari sistem Agribisnis Pengolahan yang dilakukan masyarakat tersebut. Tujuan yang ingin di capai dari penelitian ini adalah untuk mengetahui Jenis-jenis hasil olahan perikanan yang diproduksi di pesisir pantai selatan Kabupaten Garut dan mengetahui sistem agribisnis pengolahan hasil perikanan di pesisir pantai selatan Kabupaten Garut.

\section{Bahan dan Metode}

Metode yang di gunakan dalam penelitian adalah metode deskriftif dengan pendekatan kualitatif dan kuantitatif. Penelitian di lakukan dari bulan Mei sampai dengan bulan Agustus 2018. Pengambilan sample dilakukan secara purposive sampling. Samplingdilakukan terhadap 30 orang pelaku usaha pengolahan ikan yang ada di enam Kecamatan (Pameungpeuk, Mekarsari, Cikelet, Caringin, Pakenjeng, Cibalong). Teknik pengambilan data dilakukan dengan melalui wawancara menggunakan intrumen berupa kuesioneryang berisi daftar pertanyaan. Dalam pengolahan data dilakukan penetapan nilai (skor) terhadap setiap pertanyaan yang berada pada setiap subsistem (subsistem pengadaan dan penyaluran Sarana produksi perikanan, subsistem usaha produksi, subsistem pasca produksi, subsistem pemasaran, subsistem jasa penunjang). Berdasarkan Skoring tersebut, maka di peroleh Potret sistem agribisnis pengolahan Hasil Perikanan di Pesisir pantai Selatan Kabupaten Garut.

\section{Hasil dan Pembahasan}

\section{Kondisi Umum Lokasi Penelitian}

Wilayah Kabupaten Garut secara geografis terletak di Jawa Barat Selatan meliputi areal seluas 3.066,88 $\mathrm{km} 2$, terdiri dari 42 kecamatan, 403 desa, dan 21 kelurahan masing-masing mempunyai ciri-ciri khusus dalam potensi wilayah baik dari segi sumber daya alam maupun sumber daya manusianya (Dinas Peternakan Perikanan dan Kelautan Garut 2013). Ibu Kota Kabupaten Garut adalah Tarogong Kidul. Kabupaten Garut salah satu kabupaten yang memiliki potensi pesisir dan lautan yang cukup besar. Pesisir dan lautan di kabupaten Garut terletak atau berbatasan :

- di wilayah Selatan menghadap Samudera Indonesia.

- Wilayah Barat berbatasan dengan pesisir Kabupaten Cianjur

- Wilayah Timur berbatasan dengan pesisir Kabupaten Tasikmalaya

Kabupaten Garut memiliki panjang garis pantai sekitar $80 \mathrm{~km}$ yang membentang di wilayah selatan meliputi Kecamatan Caringin, Mekarmukti, Bungbulang, Pakenjeng, Cikelet, Pameungpeuk dan Cibalong.Dalam perkembangan Tempat Pelelangan Ikan (TPI) di Kabupaten Garut Cilauteureun merupakan sentra dari keempat Tempat Pendaratan Ikan (TPI) yang tersebar di pantai selatan Garut dengan jumlah armada penangkapan motor (KM) 15 unit, motor tempel 168 unit dan perahu tanpa motor 13 unit.

Selain TPI Cilauteueureun terdapat pula TPI Cimari, Rancabuaya dan Sancang (Hilda, 2010).Potensi perikanan tangkap diantara-nya Tuna, Tongkol, Cakalang, Cumi-cumi, Layur, Kakap, Bawal Hitam, Kerapu, Baronang, Cucut Botol, Lobster dan ikan khias. Khusus untuk area penangkapan sam-pai zona teritorial (12 mil laut) diperkirakan pesisir selatan Garut memiliki potensi lestari (Maximum Sustainable Yield) sebesar 10.000 ton/tahun. Saat ini nelayan Kabupaten Garut baru memanfaatkan sekitar 49,94\% dari potensi yang ada (Selvi, 2017).

\section{Gambaran umum Karakteristik pengolah (responden)}

Variabel yang dipergunakan dalam melihat profil responden pengolahan hasil perikanan antara lainumur, tingkat pendidikan, jumlah anggota keluarga, 
pengalaman mengolah ini terkait dengan keterampilan manajemen usaha, yang pada akhirnya mempengaruhikuantitas dan kualitas olahan yang dihasilkan. Terdapat Kecamatan pesisir yang mayoritas perempuan bermata pencaharian sebagaipengolahhasil perikanan yaitu di 6 Kecamatan .KecamatanMekar Mukti, Cikelet, Caringin, Cibalong, Pakenjeng dan Kecamatan Pameungpeuk.Jumlah respondenyang terpilih sebanyak 30 orang ditetapkan secara sengaja, dengan memperhatikan produk olahan yang di hasilkan.

\section{Karakteristik Responden}

Hasil penelitian menunjukkan bahwa Karakteristik responden penelitian dengan umur antara 21 - 60 tahun sebagian besar pada kategori sedang 56,7 \%. Produktivitas seseorang dapat dilihat dari beberapa faktor diantaranya adalah umur.Karena, umur mempengaruhi kemampuan fisik, kesehatan mental dan spiritual dalammelakukan aktivitas.Seseorang yang lebih muda cenderung lebih mudah menerima hal halbaru dan bersikap lebih dinamis daripada orang yang memiliki umur yang lebih tua. Pendidikan responden paling rendah SD paling Tinggi Strata 1, tingkat pendidikkan sebagian besar masuk kedalam kategori rendah 46,6 \%dan tinggi 40\%. Dengan pendidikkan yang lebih tinggi dan cenderung untuk berani menanggung resiko (Sihombing 2013, dalam Ganjar 2017) Pengalaman Usaha responden terendah 1 tahun dan tertinggi 25 tahun, dan sebagian besar berada pada katagori Sedang dan tinggi yaitu 96,6 \%. Secara lengkap sebaran karakteristik Responden berdasarkan umur, pendidikkan dan pengalaman usaha pada Tabel 1.

Tabel 1. Sebaran Karakteristik Responden Berdasarkan Umur, Pendidikkan Formal dan Pengalaman Usaha Pesisir Pamtai Selatan kabupaten Garut

\begin{tabular}{|c|c|c|c|c|c|c|c|}
\hline No & $\begin{array}{l}\text { Karakteristik } \\
\text { Responden }\end{array}$ & & Kriteria & Kategori & $\begin{array}{l}\text { Jumlah } \\
\text { Orang }\end{array}$ & $\begin{array}{l}\text { Persentase } \\
\text { (\%) }\end{array}$ & Interval \\
\hline \multirow[t]{3}{*}{1} & Umur (Tahun ) & & Muda & $<27$ & 2 & 6,6 & $(21-60)$ \\
\hline & & & Sedang & $27-50$ & 17 & 56,7 & tahun \\
\hline & & & Tua & $>50$ & 5 & 16,6 & \\
\hline \multirow[t]{4}{*}{2} & Pendidikkan & & Rendah & SD & 14 & 46,6 & SD- S1 \\
\hline & & & Sedang & SMP & 4 & 13,3 & \\
\hline & & & Tinggi & SMA, & 9 & 30 & \\
\hline & & & & S1 & 3 & 10 & \\
\hline \multirow[t]{3}{*}{3} & $\begin{array}{l}\text { Pengalaman } \\
\text { (tahun) }\end{array}$ & usaha & Rendah & $<5$ & 1 & 3,3 & $\begin{array}{l}(5-20) \\
\text { tahun }\end{array}$ \\
\hline & & & Sedang & $5-20$ & 14 & 46,6 & \\
\hline & & & Tinggi & $>20$ & 15 & 50 & \\
\hline
\end{tabular}

Sumber :Data Primer di olah ( 2018)

\section{Kinerja Agribisnis Pengolahan Ikan}

Ikan Segar dan rumput laut di olah menjadi berbagai hasil produk olahan yang di produksi oleh kelompok Pengolah dan pemasar di 6 Kecamatan di pesisir Selatan Garut, berupa ikan Asin , Abon ikan, Nuget, Baso, Baso Tahu, Abon, ikan asap, kerupuk, peyek ikan teri dan dari rumput laut berupa agar-agar. Pengolahan yang di lakukan istri nelayan ini ada yang di lakukan setiap hari namun ada juga yang di lakukan 1 minggu 2 kali dan 1 minggu 1 kali. Terdapat 74 kelompok yang menggeluti usaha pengolahan dan pemasaran dengan produk segar dan hasil olahan dan 1 kelompok di antaranya sebagai kelompok penghasil kerajinan kerang. Para pengolah sebagian besar kaum perempuan mereka mengawali usahanya di sebabkan oleh berlimpahnya bahan baku hasil tangkapan nelayan, dan juga untuk memenuhi kebutuhan rumah tangga, yang tidak bisa hanya mengandalkan penghasilan dari suaminya saja. 
Tabel 2. Profil Produk olahan Pesisir Pantai Selatan Kabupaten Garut

\begin{tabular}{|c|c|c|}
\hline No & Jenis Olahan & Deskripsi \\
\hline 1 & Ikan asin & $\begin{array}{l}\text { Ikan asin merupakan daging ikan yang di awetkan dengan } \\
\text { menambahkan banyak garam, pengawetan dilakukan secara alami } \\
\text { dengan menggunakan sinar matahari, dapat di simpan berbulan-bulan } \\
\text { bertahan lebih lama Jenis ikan yang digunakan ikan Marlin ikan } \\
\text { tuna, ikan kue, ikan jambal,ikan gabus }\end{array}$ \\
\hline 2 & Ikan pindang & $\begin{array}{l}\text { Ikan pindang adalah produk awetan dengan kadar garam rendah, ikan } \\
\text { yang di garami dan di bumbui kemudian di rebus sampai kering. } \\
\text { Memiliki citarasa, tekstur dan keawetan yang khas. Jenis ikan yang } \\
\text { digunakan, ikan tuna }\end{array}$ \\
\hline 3 & Abon Ikan & $\begin{array}{l}\text { Abon adalah makanan yang terbuat dari serat daging hewan dalam } \\
\text { hal ini ikan, berwarna coklat terang hingga kehitaman, tampak } \\
\text { seperti serat-serat kapas. Jenis ikan yang digunakan ikan tongkol }\end{array}$ \\
\hline 4 & Baso ikan & $\begin{array}{l}\text { Baso adalah gumpalan daging yang lazim di temui dalam masakan, } \\
\text { terbuat dari campuran daging ikan dan tepung tapioka. Jenis ikan } \\
\text { yang digunakan ikan tuna, tongkol, cumi-cumi, cakalang }\end{array}$ \\
\hline 5 & Kerupuk ikan & $\begin{array}{l}\text { Kerupuk adalah di buat dari adonan tepung tapioka dengan perasa } \\
\text { ikan. Jenis ikan yang digunakan ikan tenggiri }\end{array}$ \\
\hline 6 & Nuget ikan & $\begin{array}{l}\text { Nuget adalah hasil pengolahan dari daging ikan dengan tamabahan } \\
\text { bahan tepung dan bumbu-bumbu, berwarna kuning keemasan. Jenis } \\
\text { ikan yang digunakan ikan tongkol }\end{array}$ \\
\hline 7 & Agar-agar kertas & $\begin{array}{l}\text { Agar-agar kertas adalah bahan hasil olahan dari rumput laut berupa } \\
\text { zat gel yang di keringkan dan di bentuk menjadi lembaran. Bahan } \\
\text { yang digunakan yaitu rumput laut }\end{array}$ \\
\hline \multicolumn{3}{|c|}{ Sumber: Data Primer di olah (2018) } \\
\hline \multicolumn{3}{|c|}{$\begin{array}{l}\text { Tabel 3. Sebaran dan Jenis Olahan yang di Produksi Pengolah Pesisir Pantai Selatan } \\
\text { Kabupaten Garut }\end{array}$} \\
\hline No & \multicolumn{2}{|l|}{ Jenis olahan } \\
\hline 1 & Ikan asin & 43,3 \\
\hline 2 & Ikan pindang & 20 \\
\hline 3 & Abon & 10 \\
\hline 4 & Nuget & 13,3 \\
\hline 5 & Baso & 3,33 \\
\hline 6 & Agar-agar & 10 \\
\hline & Jumlah & 100 \\
\hline
\end{tabular}

Sumber : Data Primer diolah (2018)

Hasil Penelitian menunjukkan pelaku usaha pengolahan sebagian besar perempuan 76,7 \% dan sebagian kecil laki-laki 23,3 \%. Informasi tentang cara pengolahan hasil perikanan merupakan salah satu aspek yang sangatpenting dalam menghasilkan produksi olahan ikan yang berkulitas. Sebagaimana diketahuibahwa lemahnya jaringan komunikasi pembudidaya dengan sumber informasi formal sepertidari penyuluh atau Dinas disebabkan oleh terbatasnya jumlah penyuluh lapangan.Oleh sebab itu, berdasarkan hasil wawancara diketahui bahwa umumnya pengolah mendapatkan informasi carapengolahan ikan dari turun temurun 90\%. Dan mengetahui cara-cara pengolahan ikan dari pengolah lainnya. Hanya 10\% mendapatkan informasi dari kelompok dan penyuluh dinas kelautan dan perikanan.

Berbagai variasi jenis olahan yang di produksi oleh rensponden meliputi ikan 
asin, ikan pindang, abon ikan, baso ikan, kerupuk, nuget dan agar-agar.Profil dari produk yang di hasilkan oleh Responden di uraikan pada Tabel 2. Sebagian besar pengolah di pesisir pantai selatan Garut memproduksi ikan asin yaitu 43,3 \%, dan yang paling kecil di produksi pengolahadalah baso ikan 3,33 \%. Sebaran dan jenis olahan yang di produksi secara lengkap dapat dapat di lihat pada Tabel 3

Di lihat dari produk yang di hasilkan para pengolah terdapat lima aspek ekonomi yaitu subsistem (subsistem pengadaan dan penyaluran Sarana produksi perikanan, subsistem usaha produksi, subsistem pasca produksi, subsistem pemasaran, subsistem jasa penunjang (M.Harja, 2017). Pada masing-masing subsistem mempunyai kriteria, penilaian dilakukan dengan menggunakan skor 1 sampai dengan 3 (skor 1 = kurang, skor 2 = cukup, skor 3 baik), maka di peroleh hasil sebagaimana di sajikan pada Tabel 4 .

Tabel 4. Rekapitulasi Penilaian (Skor) berdasarkan sub sistem Agribisnis Pengolahan Hasil Perikanan di Pesisir Pantai Selatan Garut

\begin{tabular}{|c|c|c|}
\hline $\mathrm{No}$ & Sub sistem dan Kriteria & Skor \\
\hline \multirow[t]{6}{*}{1} & Sub sistem sarana Produksi & \\
\hline & a. Status kepemilikan & 2,5 \\
\hline & b. Jumlah Sarana & 2,7 \\
\hline & c. Ketersediaan Sarana & 2,5 \\
\hline & Jumlah & 7,7 \\
\hline & Rata-rata & 2,6 \\
\hline \multirow[t]{8}{*}{2} & Sub sistem Produksi & \\
\hline & a. Skala Produksi & 1,9 \\
\hline & b. Teknik Produksi & 1,06 \\
\hline & c. Jenis Hasil Pproduksi & 3 \\
\hline & d. Jumlah serapan tenaga kerja & 1,5 \\
\hline & e. Orientasi usaha & 2,74 \\
\hline & Jumlah & 10,2 \\
\hline & Rata-rata & 2.04 \\
\hline \multirow[t]{6}{*}{3} & Sub Sistem Pasca Produksi & \\
\hline & a. Teknik pengemasan & 1,06 \\
\hline & b. Bahan Pengemasan & 2,2 \\
\hline & c. Teknik Pasca Panen & 3,74 \\
\hline & Jumlah & 7 \\
\hline & Rata-rata & 2,3 \\
\hline \multirow[t]{7}{*}{4} & Sub Sistem Pemasaran & \\
\hline & a. Strategi pemasaran & 2,3 \\
\hline & b. Strategi pembayaran & 2,7 \\
\hline & c. Promosi & 1,8 \\
\hline & d. Fungsi Pemasaran & 2,5 \\
\hline & Jumlah & 9,3 \\
\hline & Rata-rata & 2,3 \\
\hline \multirow[t]{7}{*}{5} & Susb Sistem layanan Pendukung & \\
\hline & a. Sarana Transportasi & 2,7 \\
\hline & b. Fasilitas Komunikasi & 2,7 \\
\hline & c. Lembaga Keuangan & 1,7 \\
\hline & d. Status Lembaga Usaha & 2,5 \\
\hline & Jumlah & 9,6 \\
\hline & Rata-rata & 2,4 \\
\hline
\end{tabular}

Sumber : Data Primer di olah ( 2018) 


\section{Sistem Agribisnis Pengolahan Ikan di Pesisir Garut}

Sub Sistem Input. Pada subsistem input terdapat beberapa aspek penting yang perlu diperhatikan diantaranya ketersediaan bahan baku ikan segar, ketersediaan bahan tambahan seperti tepung tapioka dan pelengkap, gula dan garam, dan permodalan. ketersediaan dana dan hal lainnya yang berhubungan dengan sarana produksi. Bahan baku sebagai bahan utama pengolahan yaitu jenis-jenis ikan seperti tongkol, tuna, cumi-cumi, kue, marlin dan rumput laut sangat mudah di peroleh. Dan Tidak ada kendala untuk memenuhinya, Bahan baku ikan segar yang digunakan oleh para pengolah berkisar antara $15 \mathrm{~kg}$ sampai $60 \mathrm{~kg}$ per produksi. Bahan baku ikan segar $90 \quad \% \quad$ responden memperolehnya dari Pantai Garut dan 10\% responden memperoleh bahan baku dari luar Garut ,kebutuhan bahan relatif tidak ada kendala. Ketersediaan bahan pelengkap juga tidak ada kendala dan mudah di perolehnya. Dengan mutu dan kualitas yang baik, harga yang relatif terjangkau. Masalah permodalan umumnya para pengolah menggunakan modal sendiri tidak mengalami kesulitan dan pengolah belum memanfaatkan lembaga keuangan yang ada.

Sub Sistem Produksi. Pada kegiatan subsistem proses produksi pengolahan ada beberapa hal penting yang harus di perhatikan diantaranya, pemilihan bahan baku, persiapan peralatan dan perlengkapan sesuai dengan kebutuhan pengolahan menyesuaikan produk yang di hasilkan. Di mulai dari pembersihan bahan Baku, pencucian, pengolahan, dan penyimpanan. Teknologi pengolahan ikan masih bersifat Tradisional dengan peralatan yang masih seadanya, dan mengandalkan tenaga manusia, sehingga hasil yang di peroleh belum maksimal, dalam jumlah yang masih terbatas. Akan tetapi para pengolah sudah memperhatikan kebersihan dan kesehatan untuk menjaga produk hasil olahan nya dari pencemaran bahan berbahaya. Hasil produksi dari responden sebagian besar 50
\%. responden memproduksi lebih dari 20 Kg per produksi . 33,3 \% responden memproduksi dalam jumlah 5 - $10 \mathrm{~kg}$ dan $13,3 \%$ responden memproduksi $10-20$ $\mathrm{kg}$, serta3,4 \% responden memperoleh hasil produksi kurang dari $5 \mathrm{~kg}$.

Sub Sistem Pasca Pengolahan. Penanganan pasca pengolahan yang di lakukan oleh pengolah, Dilihat dari teknik pengemasan 93,3 \% responden masih menggunakan teknik Tradisional. 6,7 \% menggunakan teknik Semi Moderen. Melihat kondisi demikian responden 93,3 \% masih mengikuti pola lama yang di terapkan secara turun temurun dalam pengemasannya, hal ini di sebabkan para pengolah belum memiliki alat-alat moderen untuk mendukung usahanya. Berdasarkan penggunaan kemasan responden yang tidak menggunakan kemasan atau langsung di tempat olahan nya, sebanyak 33,3 \%, 26,6 $\%$ responden menggunakan kemasan daun atau kertas, dan 53,3 \% responden yang menggunakan kemasaran plastik. Jenis kemasan yang di gunakan menyesuaikan dengan produk yang di hasilkan.

Sub Sistem Pemasaran. Pada sub sistem ini yang perlu di perhatikan adalah Strategi pemasaran, Strategi pembayaran, promosi dan fungsi pemasaran . Dilihat dari Strategi pemasaran 16,6 \% Tradisional, 33,3 \% semi moderen, 3,3 \% Moderen . Dilihat dari hasil penelitian bahwa 33,3 \% merupakan angka tertinggi yang menunjukkan bahwa responden sudah mulai menggunakan strategi secara semi moderen responden sudah mulai menentukan target pasar, mecari pelanggan untuk kelancaran pemasaranannya.

Strategi pembayaran yang diterapkan para pengolah, secara kredit $6,6 \%$, secara tunai dan kredit 16,6 \% dan 76,6 \% secara tunai. Hasil penelitian menunjukkan sistem pembayaran terbesar yang di lakukan adalah secara tunai, hal ini terjadi karena para pengolah banyak yang melakukan pemasaran nya di daerah pantai secara langsung. 
Kegiatan promosi produk yang dilakukan para pengolah menggunakan Tradisional yaitu $40 \%$,Para pengolah masih menerapkan pola lama dan belum menggunakan media sosial, sebab tidak di dukung kemampuan dan fasilitas yang dimiliki dan responden yang sudah melakukan promosi semi moderen 40 \%.Para pengolah sudah mulai menerapkan promosi dengan cara menggunakan media tercetak dan sedikit media sosial serta yang moderen $20 \%$ yang lebih moderen di dukung kemampuan dan fasilitas, pemasaran on line.

Hasil Rekapitulasi penilaian (Skor) masingmasing sub sistem kinerja agribisnis pengolahan di Pesisir Pantai Selatan Kabupaten Garut di sajikan pada Tabel 4.

Sub Sistem Lembaga Penunjang. Lembaga merupakan fenomena yang sangat penting dalam kehidupan masyarakat, bukan saja karena fungsinya untuk menjaga dan mempertahankan nilai-nilai yang sangat tinggi dalam masyarakat, melainkan juga berkaitan erat dengan pelbagai kehidupan manusia.Maka ada yang memahami lembaga sebagai sarana untuk mencapai tujuan atau kebutuhan manusia. Terlepas dari ketepatan artinya, lembaga sosial mempunyai peranan yang sangat vital dalam kehidupan masyarakat, termasuk masyarakat pedesaan. Secara umum dalam suatu masyarakat, khususnya Negara, lembaga-lembaga yang sangat penting perannya dalam kehidupan masyarakat tersebut adalah lembaga pemerintahan, ekonomi, pendidikan, agama dan keluarga, namun dalam buku sosiologi pedesaan kupasan lembaga kemasyarakatan akan lebih banyak di tunjukan pada lembaga pemerintahan desa serta yang terkait dengan itu. Sebab, untuk masyarakat desa di Indonesia umumnya, lembaga pemerintahan ini memiliki peranan yang penting. Lembaga penunjang yang ada seperti sarana transportasi relatif mudah di peroleh, fasilitas komunikasi responden sudah menggunakan telepon genggam, serta lembaga keuangan cukup memadai namun tingkat pemanfaatan nya masih relatif rendah. Status kelembagaan usaha bervariasi ada yang milik sendiri dan milik bersama atau kelompok.Pengembangan Lembaga Ekonomi Pedesaan didirikan dengan tujuan adalah untuk meningkatkan usaha ekonomi masyarakat, pengembangan lembaga ekonomi Desa dan pemberdayaan masyarakat miskin.

Lembaga Ekonomi dan Unit Usaha Desa seperti pasar , bank, kelompok tani, koperasi , buruh , dan berbagai macam unit usaha dipedesaan adalah pilar atau penyangga ekonomi yang diharapkan mampu mendukung dan menopang kegiatan pembangunan dipedesaan dalam berbagai bidang. Lembaga ekonomi pedesaan dibentuk guna untuk mengembangkan , membina , mengayomi , dan menampung aspirasi serta segala bentuk potensi perekonomian khususnya yang ada di pedesaan , guna untuk meningkatkan daya saing dan nilai dari kegiatan usaha yang ada didesa baik dalam skala mikro maupun makro. Pengembangan Usaha Ekonomi Masyarakat Desa adalah lembaga usaha desa yang dikelola oleh masyarakat dan pemerintahan desa dalam upaya Pembangunan sektor-sektor perdesaan (tradisional; agrokompleks) dengan mendorong pertumbuhan sektor industri melalui penyediaan bahan pangan. kelembagaan wilayah pesisir Kabupaten Garut dapat diketahui pada kegiatan pengadaan dan penyaluran sarana produksi usaha perikanan seluruh Kecamatan sudah memiliki potensi dukungan kelembagaan yang baik.

\section{Kesimpulan}

Kegiatan Penelitian yang telah dilakukan dapat disimpulkan sebagai berikut: diperoleh infomasi jenis-jenis olahan yang di produksi di wilayah pesisir pantai selatan Kabupaten Garut meliputi, ikan asin, ikan 
pindang, abon ikan, baso ikan, kerupuk, nuget, agar-agar.

Selanjutnya di tinjau dari lima subsistem usaha di peroleh nilai (Skor) Subsistem pengadaan dan penyaluran sarana $(7,7)$, Subsistem usaha produksi, $(10,2)$, Susistem pasca produksi (7), Subsistem pemasaran $(9,3)$, Sub sistem jasa penunjang $(9,6)$ dari hasil penilaian tersebut di peroleh potret agribisnis pengolahan hasil perikanan di Pesisir Selatan Kabupaten Garut, dimana dari masing-masing sub system menunjukkan jumlah skor berada pada kategori tinggi, hal ini menunjukkan bahwa masing-masing sub system tidak mengalami kesulitan yang berarti, dan kegiatan bisnis pengolahan ikan bias dan berpotensi untuk di kembangkan. Hasil Penelitian ini dapat di jadikan referensi untuk mengembangkan kegiatan pengolahan hasil perikanan di pesisir selatan Kabupaten Garut.

\section{Persantunan}

Penulis mengucapkan terimakasih kepada pihak dinas Perikanan Kabupaten Garut, para penyuluh, para pengolah yang telah membantu dalam proses pengumpulan data berupa informasi dan data-data yang berhubungan dengan penelitian.

\section{Daftar Pustaka}

Arikunto. 2006. Manajemen Penelitian. Rineka Cipta, Jakarta.

Badan Pusat Statistik, 2011. Kabupaten Garut dalam Angka 2011, BPS, Pemda Kabupaten Garut,

Ganjar Wiryati, 2017. Kontribusi ekonomi produktif wanita bagi keluarga Nelayan di Waduk Jati Gede Kecamatan Darmaraja, Kabupaten Sumedang. Prosiding Simposium Nasional Ikan dan Perikanan, Jilid 2. Masyarakat Ikhtiologi Indonesia.ISBN:978-602-60693-3-7

Harper S Zeller dkk, 2013. Women and Fisheries Contribution of food security and lokall ekonomis J marpelo Vol. 39.

Hilda, dkk, 2010. Penyusunan data Spasial Sumberdaya Alam dan Kebencanaan sebagai Acuan RTRW dan Pengembangan di Garut Selatan, LIPI

Imron, 2005. Pengantar Bisnis Budidaya Ikan Hias, Jakarta, Swadaya.

M.Harja, 2017.Profil Aktivitas Ekonomi Masyarakat Perikanan Sekitar Waduk Jawa Barat. Prosiding Simposium Nasional Ikan dan Perikanan, Jilid 2. Masyarakat Ikhtiologi Indonesia. ISBN:978602-60693-3-7

Nainggolan, T.Y., K. Sumantadinata dan A. Suryani. 2010. Strategi Pengembangan Usaha "Nila Puff" dalam Meningkatkan Pendapatan IKM Pengolahan Hasil Perikanan pada CV.”X” di Cibinong, Bogor. Manajemen IKM, 5(2): 132-144.

Nasir,Moch.2006.Metode Penelitian. Jakarta : PenerbitGhalia Indonesia

Satori, D. dan A. Komariah.(2010). Metodologi Penelitian Kualitatif.Alfabeta.Bandung.

Saragih, B. 2010. Agribisnis : Paradigma Baru Pembangunan Ekonomi Berbasis Pertanian. PT. Penerbit IPB Press, Bogor.

Sa’id, E.Gumbira dan A.Harizt Intan. 2001. Manajemen Agribisnis. Jakarta : Ghalia Indonesia.

Siagian, Renville. 2003. Pengantar Manajemen Agribisnis. Yogyakarta : Gadjah Mada University Press.

Selvi, T dkk, 2017. Kontibusi Pendapatan kelompok usaha perempuan pesisir dalam pengolahan hasil perikanan di Manokwari, Jurnal Suberdaya aquatik Indofasifik. Vol. 1 no. 2 November 2017. 